\title{
Het wetgevingsproces in de externe berichtgeving door gemengde financiële concerns
}

Laurence van Lent

\section{Inleiding 1}

De wijze waarop in Nederland de regelgeving op het gebied van de externe berichtgeving is georganiseerd. biedt doorgaans weinig gelegenheid tot een nadere analyse van wetgevingsprocessen op Nederlands niveau. Enerzijds zijn of worden veel aspecten op Europees niveau gedirigeerd, anderzijds heeft de wetgever een ruime rol toebedeeld aan buitenparlementaire regulering. Door toevallige omstandigheden die verderop in dit artikel worden geschetst. deed zich echter aan het begin van de jaren negentig (1990-1994) een unieke gelegenheid voor tot een grondige bestudering van hel Nederlandse wetgevingsproces. In deze periode vond de implementatie plaats van de Wet inzake de (geconsolideerde) jaarverslaggeving door banken (nr. 22169) en de Wet inzake de (geconsolideerde) jaarverslaggeving door verzekeringsmaatschappijen (nr. 22896). Deze wetten schrijven voor op welke wijze de verslaggeving door gemengde financiële concerns moet worden vormgegeven.

Gemengde fïnanciële concerns worden gekenmerkt door het leit dat ze zowel in het bank-als verzekeringswezen actief zijn. Als voorbeeld van dergelijke concerns kan worden genoemd: ING, Rabobank, en Fortis. De term wordt echter vooral gebruikt voor concerns met ongeveer gelijke belangen in bank- en verzekeringsactiviteiten. zoals ING en Fortis.
De centrale kwestie in de regelgeving betrof de vraag of de bank- en verzekeringsactiviteiten van gemengde financiële concerns geconsolideerd mogen worden weergegeven in de jaarrekening. en zo ja, of het wenselijk is om aanvullende informatie omtrent de individuele activiteiten te verstrekken. In dit artikel besteed ik niet zozeer aandacht aan de normatieve vraag wat de juiste wijze van verslaggeving voor financiële concerns is. Veel meer staat centraal op welke wijze de wetgeving tot stand is gekomen. Met name richt ik mij op de interactie tussen belangengroepen onderling en die in samenspel met de Nederlandse overheid.

Het artikel is als volgt ingedeeld. In paragraaf twee worden enige methodologische aspecten van de gevalsstudie in regelgevingsonderzoek alan de orde gesteld. Paragraaf drie beval een korte beschrijving van het institutionele kader van gemengde financiële concerns. Vervolgens wordt in paragraaf vier het wetgevingsproces beschreven vanaf de aanname van de EEG-richtlijnen inzake de jaarverslaggeving door banken tot aan de acceptatie van de Nederlandse aanpassingswet. Eenzelfde beschrijving volgt voor het proces van de EEG-richtlijnen voor de jaarverslaggeving door verzekeringsmalatschappijen tot de acceptatie van de bijbehorende Nederlandse aanpassingswet (paragraaf vijf). De rol van de accountants in de wetgevingsprocedure is onderwerp van bespreking in paragraaf zes. Paragraaf zeven, ten slotte, bevat een afrondende beschouwing.

\section{Enige methodologische overwegingen}

In deze paragraaf wordt de keuze voor de gevalsstudiemethodologie gemotiveerd (2.I) en 
vervolgens wordt het onderzoeksontwerp van deze studie uiteengezet aan de hand van vier kwaliteitscriteria van gevalsstudie-onderzoek zoals beschreven door Yin (1989) (2.2).

\subsection{Motivatie van de keuze voor de gevalsstudie-methode}

Voor het in kaart brengen van de interactie tussen belangengroepen is gebruikgemaakt van de gevalsstudie-methodologie. De economische lobbyliteratuur heeft tot voor kort vooral veel gebruikgemaakt van waarneembare 'comment letters' gericht aan de regelgever (een wijze van aanpak die is ingegeven door de baanbrekende bijdrage van Watts en Zimmerman, 1978).

Het succes van belangengroepen hangt echter goeddeels af van de mate waarin de beïnvloedingsactiviteiten buiten de openbaarheid kunnen worden vormgegeven (Sutton, 1984). Een analyse van de openbare 'comment letters' is dan ook waarschijnlijk niet de beste methode van lobbyonderzoek (Lindahl, 1987).

Deze zogenoemde Sutton-Lindahl kritiek suggereert dat een onderzoekontwerp wenselijk is waarin wordt getracht alle lobbymethoden in kaart te brengen om zodoende een volledig beeld te schetsen van de gang van zaken. Een gevalsstudie lijkt daarbij een bijzonder kansrijk alternatief, aangezien het de mogelijkheid biedt om tevens een kijkje te nemen achter de publieke schermen en deze gegevens systematisch in de analyse te betrekken (Walker en Robinson, 1993).

Een gevalsstudie is te meer wenselijk omdat veel lobbystrategen, vooral in vakbonden en werkgeversorganisaties, een lange-termijnperspectief hebben en meerdere strijdpunten in hun plan betrekken. Onderzoeksmethoden die slechts één strijdpunt in ogenschouw nemen of een beperkte tijdsperiode omvatten zijn minder effectief in het verklaren van het beïnvloedingsgedrag van betrokken partijen (Amershi et al., 1982).

\subsection{De beoordeling van de kwaliteit van een gevalsstudie}

De kwaliteit van een gevalsstudie kan worden beoordeeld op vier criteria: interne en externe validiteit, ontwerpvaliditeit en betrouwbaarheid (Yin, 1989). Het ontwerp van deze studie wordt aan de hand van de genoemde vier criteria nader besproken.

\section{Ontwerpvaliditeit}

De ontwerpvaliditeit heeft betrekking op de verzameling van gegevens. Drie principes zijn in dit proces van belang: het gebruik van meerdere gegevensbronnen, de goedkeuring van het ontwerp-verslag door de informanten in de studie, en het onderhouden van een 'keten van bewijsstukken ". In dit onderzoek zijn drie gegevensbronnen gebruikt: verslagen, archiefmateriaal en interviews. De verslagen en het archiefmateriaal omvatten het Official Journal of the European Communities 31.1286 nr. L372 en 31.12.91. nr. L374. Voorts de handelingen van de Eerste en Tweede Kamer met betrekking tot de wetsvoorstellen 22169 en 22896, het 1992-adviesrapport van de Nederlandse Vereniging van Banken en het Verbond van Verzekeraars, de jaarverslagen van financiële conglomeraten 1990-1994, alsmede artikelen in de financiële pers. Artikelen uit $\mathrm{Het}$ Financieele Dagblad werden geselecteerd met behulp van een database. Zoekwoorden waren hier: 'bankwezen' en 'verzekeringswezen' voor de periode 01 januari 1989 tot 01 januari 1994. Deze zoekactie resulteerden in 7239 artikelen die vervolgens werden beoordeeld op hun relevantie voor de case. Ten slotte is gebruikgemaakt van een casestudy-verslag door Barkema, Douma en Steins Bisschop (1992) over de fusie van de NMB-Postbank en Nationale Nederlanden.

De interviews hadden de vorm van 'focused interviews' (Yin, 1989). Dit wil zeggen dat in de gesprekken werd gebruikgemaakt van open-einde vragen. De vragen waren afkomstig uit een 'casestudy protocol' (zie onder betrouwbaarheid). Een belangrijk doel van de interviews was het bevestigen van feiten die naar voren kwamen in de overige bronnen. Verder werd uitdrukkelijk gevraagd naar de persoonlijke mening van de informanten over het regelgevingsproces.

De informanten werden gekozen op basis van een analyse van de hoofdrolspelers in artikelen in de financiële pers. De informanten werd verder gevraagd andere sleutelspelers in het regelgevingsproces te noemen.

Deze twee procedures leidden tot een beperkte groep van gegadigden die vervolgens werd uitgenodigd voor een vraaggesprek. Alle benaderde 
gegadigden gingen akkoord mel een vralaggesprek. De interviews werden afgenomen in de periode juli-september 1994 en duurden over het algemeen twee tot drie uur. Van alle interviews zijn bandopnamen gemaakt. die vervolgens werden bewerkt tot samenvattingen van de gesprekken. De bandopnamen zijn vanwege geheimhoudingsovereenkomsten niet beschikbaar. Tabel 1 (in de bijlage) verstrekt meer details. De validiteit van het onderzoek werd verder versterkt door in dit artikel alleen informatie op te nemen die door ten minste twee andere bronnen is bevestigd (het principe van triangulatie).

Alle gespreksdeelnemers hebben een voorlopige versie van hel onderzoeksverslag toegestuurd gekregen. Twee informanten (S. Wortmann en R. Boezer) hadden daadwerkelijk opmerkingen op het verslag. Naar aanleiding hiervan zijn hun suggesties in het uiteindelijke verslag overgenomen.

Volgens Yin (1989) is het van belang een keten van bewijsstukken te onderhouden. Feitelijk betekent dit dat er een duidelijke relatie moet zijn tussen de gerapporteerde conclusies en de gegevens uit de databronnen. Omwille van de leesbaarheid is het aantal noten in dit artikel beperkl gehouden, waardoor aan dit vereiste niet altijol volledig wordt voldaan. Een volledig verantwoorde versie van dit artikel is beschikbaar als Van Lent (1995).

\section{Interne en externe raliditeit}

Interne en externe validiteit zijn minder relevant in dit artikel, aangezien niet getracht wordt een verklaring te geven voor het gedrag van partijen. Ook wordt niet getracht een theorie te bevestigen of falsifiëren, noch wordt een poging gedaan om de conclusies van dit onderzoek te generaliseren (zie daarvoor Van Lent ( 1997)).

\section{Betroumbaarheid}

De betrouwbararheid van dit onderzoek werd gegarandeerd door twee strategieën. Ten eerste is een casestudy protocol geschreven dat op verzoek beschikbaar is. Ten tweede is een verzameling aangelegd van in hel onderzoek gebruikte gegegevens. Het casestudy protocol omvat het onderzoeksinstrument (de vragenlijst en de regels en procedures die gebruikt zijn bij de toepassing van de vragenlijst). Ook bevat het protocol een overzicht van het gehele project, dat wil zeggen achtergrondinformatie. aanbevelingsbrieven, doelstellingen van het onderzoek, onderzoeksprocedures, inleidingen tot vraaggesprekken. strategieën voor het benaderen van informanten en een handleiding voor het schrijven van het onderzoeksverslag.

De gegevensverzameling van het onderzoek omvat alle aantekeningen die gemaakt zijn gedurende het project, de verslagen van de interviews alsmede alle documenten en archiefstukken die zijn gebruikt. Ook deze gegevensverzameling is op verzoek toegankelijk.

In dit gevalsstudieverslag wordt het regelgevingsproces beschreven van twee wetsvoorstellen watarin de rapporteringsverplichtingen van gemengde financiële concerns zijn vormgegeven. Het verdient aanbeveling bijzondere andacht te schenken aan de interactie tussen de managers van de financiële concerns, de betrokken accountants, het Ministerie van Justitie, het parlement, de Raad voor de Jaarverslaggeving. De Nederlandsche Bank. de gebruikers van de externe berichtgeving (in het bijzonder (le financiële pers), en bedrijfslakorganisaties. Voor het beoordelen van de gebcurtenissen in dit wetgevingsproces is het bchulpzaam kort een overzicht te schetsen van het institutioneel kader waarmee gemengde financiële concerns worden geconfronteerd. De volgende paragraaf is daaraan gewijd.

\section{Institutioneel kader van financiële concerns}

Op financiële concerns in Nederland wordt toezicht gehouden door De Nederlandsche Bank (DNB) en de Verzekeringskamer, voor bancaire respectievelijk verzekeringsactiviteiten.

DNB heeft een belangrijke taak in het monetaire beleid van het land. Daarenboven is zij belast met het garanderen van de stabiliteit van het Nederlandse financiële systeem. De Verzekeringskamer is een gelijksoortig orgaan dat zich concentreert op het toezicht op de verzekeringsbranche.

Tot 1990 was DNB gebonden aan het "structuurbeleid" waarin onder meer was bepaald dat banken en verzekeringsmaatschappijen niel konden fuseren. Aan dit beleid lag met name mededingingspolitiek ten grondslag. Vanaf I januari 1990 werd dit deel van het structuurbeleid opgeheven met als gevolg dat op de Neder- 
landse financiële markt een fusiegolf op gang kwam. Gelijktijdig werden op EG-niveau twee richtlijnen geimplementeerd over de externe berichtgeving door banken en verzekeringsmalatschappijen. Blijkbaar was ten tijde van de opstelling van deze EEG-richlijnen het ontstaan van gemengde financiële concerns niet voorzien, aangezien er geen voorzieningen werden getroffen voor dit soort ondernemingen. Dit gaf de nationale regelgever de gelegenheid verslaggevingsvoorschriften op te stellen. Men bedenke dat gemengde financiële concerns noch aan de verslaggevingsvoorschriften voor banken. noch aan de voorschriften voor verzekeringsmaatschappijen behoelden te voldoen (Memorie van Toelichting. 22169 A:1). Aangezien het BW geen nadere regelingen specifick voor gemengde financiële concerns bevat. rest de conclusie dat deze ondernemingen eenvoudigweg onderworpen zijn aan de vierde en zevende EEG-richtlijnen en de algemene vereisten van het Nederlandse BW.

Eén van deze eisen in Titel 9 betreft de verplichting tol consolidatie van alle dochtermaatschappijen in een groep en van alle groepsdelen (artikel 406. lid 1, BW). Op deze regel kan een uitzondering worden gemaiki. indien de consolidatie het insicht dat nodig is voor de oordeelsvorming over de financiële positie van een onderneming belemment (het inzichtsprincipe). De jaarrekening van het betreffende ondernemingsonderdeel dient dan gepubliceerd te worden in de toelichting op de jaarrekening van de groep. Het inzicht kan potentieel worden belemmerd door verschillen in activiteiten tussen een groepsdeel en de groep als geheel (art. 406. lid 3). In de juridische literatuur over lid 3 van artikel 406 wordt het voorbeeld van banken en verzekeringsmaatschappijen expliciet vermeld als een geval watrin verschillen in activiteiten consolidatie kunnen voorkomen (Burgert et al. 1990. p. 596 en Handelingen Tweede Kanner. 19813. nr. 3).

Twee accounting-vraagstukken stonden centraal in de wetgevingsprocedure waarin de verslaggevingsvoorschriften van linanciële concerns werden geregeld.

I Dienen bank-en verzekeringsactiviteiten geconsolideerd te worden in één jalarrekening?

2 Indien consolidatie wordt toegestaan. welke aanvullende informatie omtrent de individuele activiteiten is in dat geval noodzakelijk?

\section{Het wetgevingsproces, deel 1: van bankenverslaggevingsrichtlijn naar wet}

Hel wetgevingsproces in de externe berichtgeving door gemengde financiële concerns kan worden verdeeld in twee fasen: (1) de impiementalie van de EEG-hankenverslaggevingsrichtlijn en (2) de implementatie van de EEG-verzekeraarsverslaggevingsrichtlijn. Paragraaf vier beschrijft de eerste fase. De tweede fase stalat centralal in paragratal vijf.

Deel I van het verslag beschrijft achtereenvolgens de rol van DNB als woordvoerder op Europees niveau (4.1), de Nederlandse voorbereidingsfalse van de wet watrin vooral de interactie tussen het Ministerie van Justitie en de bedrijlstak centrial staat (4.2) en ten slotte de parlementaire behandeling van het wetsvoorstel (4.3).

\section{I De EEG-richtlijn en de rol ran De Nederlandsche Bank}

De vierde EEG-richtlijn bood de nationale wetgever lijdelijk de mogelijkheid om banken. andere financiële instellingen en verzekeringsmaatschappijen uit te sluiten van de vereisten van deze richtlijn (PbEG L222. 14 augustus 1978. artikel 1. lid 2). met het oog op nadere regulering van de bijzonder geachte bedrijlistak. De Nederlandse wetgever heeft indertijd van deze mogelijkheid geen gebruikgemakt. De nadere regulering kreeg een eerste invulling mel de invoering van de richnlijn betreffende de jalarrekening en de geconsolideerde jaurrekening van banken (hiernal de bankenverslaggevingsrichtlijn) op 8 december 1986 (PbEG L372. 31 december 1986). In de voorbereidingsfase van deze richtlijn stond de Nederlandse delegatic onder leiding van DNB. DNB was van mening dat consoliclatie van banken verzekeringsactiviteiten in één jaarrekening niet toegestaan zou mogen worden, en dit was tevens de communis opinio onder de overige delegaties (Memorie van Toelichting. 22169 A: 1: interview met R. Boezer).

Opgemerkt dient te worden dat het consolidalievraagstuk nauwelijks een discussiepunt was in de EG-beraadslagingen. DNB voorzag evenmin als andere delegaties dat gemengde financiële concerns een dermate belangrijke organisatievorm binnen het financiële systeem zouden worden. 
Branchevreemdheid zou consolidatie van bank-en verzekeringsactiviteiten onmogelijk maken.

DNB kwam verder tot haar standpunt op basis van de gedachte dat de verslaggevingspraktijk binnen een bedrijfstak zo weinig mogelijk moch1 verschillen. Het beperken van de keuzen in de verslaggevingsmethodiek van bedrijven is dan een logische reactie. Niet-consolideren vormde daarbij het uitgangspunt (interview met R. Boezer).

Toen een iantal van de belangrijkste Nederlandse fïnanciële ondernemingen als gemengd financieel concern ging opereren en de bankenverslaggevingsrichtlijn werd omgezet in een wetsvoorstel door het Nederlandse Ministerie van Justitie. wijzigde DNB haar koers. Consolidatie was niet langer een onoverkomelijk bezwaar. De druk op DNB tot koerswijziging was dan ook in toenemende mate voelbaar. Als toezichthouder wordt DNB voortdurend geconfronteerd met strijdpunten met het bankwezen. Het vraagstuk van de consolidatie was in de totalafweging van onvoldoende belang om de delicate relatie tussen DNB en het bankwezen te verstoren (interview met $\mathrm{S}$. Wortmann). Ook binnen DNB was inmiddels enig begrip ontstaan voor de wens van de nieuwgevormde ondernemingen om hun totale financiële draagkracht kenbaar te maken aan de markt (interview met R. Boezer).

Desalniettemin bleef DNB van mening dat gezien de toonaangevende rol die de gemengde financiële concerns op de Nederlandse financiële markt zouden gaan spelen. de publicatie van voldoende nadere informatie noodzakelijk was. Met name een separate verslaggeving van de activiteiten van het bank- en het verzekeringssegment werd onmisbaar geacht.

Een ander punt van belang betrof de wens van DNB inzake congruentie van de maandstaten. die de banken verplicht zijn in te dienen, en de jaarrekening. Een reden voor deze wens betreft de boekhoudkosten die gepalard gaan met het voldoen aan de verslaggevingsvoorschriften (interview met R. Boezer). Maar er kan ook gewezen worden op het belang dat DNB heeft bij het beperken van de informatieasymmetrie tussen de toezichthouder. die immers beschik1 over de extra gegevens uit de maandstaten. en het algemeen publick. Mocht de informatieasymmetrie te groot worden. dan is DNB kwetsbaar voor aantijgingen van inadequat toezicht en kan ze beschuldigd worden het publiek niet voldoende tijdig op de hoogte te hebben gesteld ingeval een bank in betalingsproblemen komt. Dergelijke aantijgingen zullen minder effect ressorteren, indien de informatieasymmetrie tot een minimum beperkt blijfi. Dit kan een alternatieve verklaring zijn voor DNB's standpunt dat publicatie van voldoende informatie in de jaarrekening noodzakelijk is.

Kortom, DNB deed een concessie wat betreft de consolidatiediscussie, maar hield voet bij stuk in het separate verslaggevingsstrijdpunt.

DNB adviseerde het Ministerie van Justitie nog geen wetsvoorstellen te formuleren. maar de ontwikkelingen op Europees niveau af te wachten. Het Ministerie achtte dit advies niet in het belang valn de gemengde fïnanciële concerns, aangezien Europese wetgeving doorgaans een lange doorlooptijd kent, en de uitkomst van hel wetgevingsproces moeilijk voorspelbaar blijkt te zijn. Het Ministerie streefde er daarom naar alle verslaggevingsverplichtingen ten spoedigste in een wettelijk kader onder te brengen, en dit in ieder geval afgerond te hebben voordat de EG met eigen richtlijnen terzake kwam (interview met S. Wortmann).

De opinies en activiteiten van DNB zijn niet allcen van belang ondat DNB een belangrijke rol heeft als toezichthouder van de gemengde financiële concerns en een niet te onderschatten macht heeft in het Nederlandse financiële systeem.

Haar rol is vooral interessant omdat DNB in het initiële wetsvoorstel een rol was toebedeeld in het meer gedetailleerd formuleren van verslaggevingscisen voor banken. De Tweede Kamer was echter gekant tegen. wat zij noemde, een dergelijke delegatie van regelgevende macht aan een privaat instituut: de centrale bank. Het bezwaar van de Kamer kwam als een volledige verrassing voor DNB, ook al omdat DNB niet door het Ministerie van Justitie was ingelicht dat een verwerping van dit onderdeel van het wetsvoorstel op handen was (interview met R. Boezer). Het is waarschijnlijk dat deze ervaring de houding van DNB in het verdere wetgevingsproces heeft bepaald.

Meer in het bijzonder is het in dil verband relevant dat de CDA-parlementariër Th. Vreugdenhil. de fractiewoordvoerder over dit onderwerp, van bronnen binnen de financiële bedrijfstak had vernomen dat er oppositie was in de 
branche tegen een meer geprononceerde rol voor DNB in de regulering van de externe berichtgeving (interview met Th. Vreugdenhil). ${ }^{2}$ DNB op haar beurt stelt dat al haar aanbevelingen en richtlijnen voor de externe berichtgeving door banken op uitdrukkelijk verzoek van de banken zelf zijn opgesteld (interview met R. Boezer). Dit feit legt een verschil bloot tussen de officiële uitingen van de banken en hun 'verborgen agenda' met betrekking tot de rol en positie van de centrale bank in het regelgevingsproces. De banken waren wellicht bevreesd dat hun positie ten opzichte van DNB verzwakt zou worden, indien DNB's taken verder zouden worden uitgebreid (interview met Th. Vreugdenhil).

\subsection{De Nederlandse voorbereidingsfase: het Ministerie van Justitie en de branche}

De EG-bankenverslaggevingsrichtlijn diende vóór 31 december 1990 in de Nederlandse wetgeving te zijn verwerkt. De Ministeries van Justitie en Financiën hadden echter tot juni 199 I nodig om met een wetsvoorstel te komen. Deze vertraging werd door de betreffende staatssecretaris (A. Kosto) verklaard door de complexiteit van de materie en de intensieve beraadslagingen met de betrokken partijen (Memorie van Toelichting 22169, no. 3, p. 3). Het is goed gebruik, volgens het Ministerie van Justitie, om in geval van wetgeving die technische en complexe materie omvat, de betrokken ondernemingen actief een rol te laten spelen in de wetsvoorstelfase. In dit geval werd onder meer AMEV, een van de onderdelen van het gemengde financiële concern Fortis, uitgenodigd aan de discussie deel te nemen (interview met S. Wortmann). In het navolgende wordt deze interactie tussen het Ministerie van Justitie en vertegenwoordigers van de betrokken bedrijfstak beschreven. Vooral wordt aandacht besteed aan de invloed van een officieel advies van de bedrijfstakverenigingen over de verslaggeving door gemengde financiële concerns.

In de Memorie van Toelichting werd door de betrokken bewindslieden vermeld dal verdere studie over het consolidatievraagstuk voor banken en verzekeringsmaatschappijen die deel uitmaken van één en dezelfde groep noodzakelijk was. Gesteld werd dat ten tijde van de formulering van de EEG-richtlijnen niet was voorzien dat banken en verzekeringsbedrijven konden fuseren en dat bijgevolg de consolidatie van beide activiteiten onderwerp van discussie zou worden. Er werd dan ook geen wetgeving voorgesteld voor de jaarverslaggeving van gemengde financiële concerns. Aangekondigd werd dat in een later stadium op deze zaak zou worden teruggekomen en dat dan tevens de bepalingen van de EEGrichtlijnen betreffende de jaarrekening en geconsolideerde jaarrekening van verzekeringsmaatschappijen (hierna: de verzekeraarsverslaggevingsrichtlijn) in de overwegingen zouden worden betrokken.

Niettemin maakten de bewindslieden van de gelegenheid gebruik om in de Memorie van Toelichting reeds enige preliminaire overwegingen kenbaar te maken. Zo vonden ze dat men niet te snel van oordeel moest zijn dat de consolidatie van bank- en verzekeringsactiviteiten strijdig is met het inzichtsprincipe. Naar hun mening waren de gemengde financiële concerns op dat moment alleen onderworpen aan de bepalingen van de vierde en zevende richtlijn. Ten slotte kondigden de bewindslieden aan dat een studiegroep bestaande uit leden van de bank- en verzekeringsbedrijfstak om advies was gevraagd over de verslaggevingseisen voor gemengde financiële concerns.

De verzekeraarsverslaggevingsrichtlijn werd door de EG op 19 december 1991 vastgesteld (PbEG L374, 31 december 1991). Tijdens de ontwerpfase van deze EEG-richtlijn was er een intensief contact tussen de verzekeringsbedrijfstak en het Ministerie van Justitie. Deze contacten werden later door het Ministerie gebruikt om de verslaggevingsbepalingen voor gemengde financiële concerns te bespreken met de meest betrokken ondernemingen. Vooral de contacten met Nationale Nederlanden (inmiddels een onderdeel van ING) waren van belang toen het Ministerie zijn standpunt in de verslaggevingsdiscussie bepaalde (interview met $\mathrm{S}$. Wortmann).

Op 31 januari 1992 presenteerde de gezamenlijke werkgroep van de Nederlandse Vereniging van Banken (NVB) en het Verbond van Verzekeraars $(\mathrm{V} v \mathrm{~V})$ het door de regering gevraagde adviesrapport 'Verslaggeving Financiële Concerns'. In dit kader zijn de voorstellen van de werkgroep over consolidatie en separate verslaggeving van belang. De werkgroep stelde, ten 
principale, dat gemengde financiële concerns zich wensten en dienden te presenteren als een ondeelbatar geheel (NVB/VvV. 1992. p. 2). Het was derhalve, aldus de werkgroep, niet nodig om separate verslaggeving door het bank- respectievelijk het verzekeringsdeel van het concern verplicht te stellen. De wens on zich te presenteren als een ondeelbaar geheel werd tevens met de nodige overtuigingskracht geuit door de ING, met name om strategische redenen (interview met W. Badon Ghijben).

De werkgroep stelde wel voor dat nadere informatie over de twee segmenten diende te worden verstrekt. In de toelichting op de geconsolideerde balans en winst- en verliesrekening dicnde in overcenstemming met het inzichtsprincipe en de vereisten van de bank- en verzekeraarsverslaggevingsrichtlijn gesegmentecrde informatie te worden verstrek1 tot op het niveau van het resultaal voor belastingen. De segmentatie kende echter een duidelijke grens in het bedrijfstakvoorstel: er zou geen nadere splitsing plaatsvinden van het eigen vermogen. Een dergelijke segmentatie. zo werd gesteld, was niet in overeenstemming met de bedrijfseconomische karakteristieken van geconsolideerde verslaggeving.

De segmentatic van het eigen vermogen zou uiteindelijk het hete hangijzer van de implementatieprocedure worden. Vooral de ING bleek uitgesproken opvattingen over dit vraagstuk te hebben. Naar de mening van de ING zouden aandeelhouders van een gemengd financieel concern zich alleen dienen te richten op het geconsolideerde vermogen. De (tocvallige) allocatie van het totale eigen vermogen over de groepsdelen is voor aandeelhouders irrelevant, alangezien verschuivingen in de allocatie de uitkomst zijn van een relatief arbitrair proces. De ING erkende dat cliënten van een bank of verzekeringsmaatschappij binnen een groep voor hun oordeelsvorming aangewezen zijn op de gepubliceerde cijfers van het betreffende bedrijfsonderdeel. Verder kan het voorkomen dat in de segmentatie van het geconsolideerde vermogen bepaalde bedrijfsonderdelen. die juridisch onderdeel zijn van het verzekeringsdeel, naar het bankdeel worden geallocecrd vanwege het specifieke karakter van het bedrijfsonderdeel in kwestie. Dat betekent echter niet dat de schulden van deze bedrijfsonderdelen gegarandeerd zijn door het bankvermogen (interview met W. Badon Ghijben).

Deze verklaring van ING verdient nadere kwalificatie. Ten tijde van de publicatie van de jaarrekening over 1991 was het nog niet duidelijk dat er (behoudens wettelijke verplichtingen) aparte jaarrekeningen zouden worden gepubliceerd door de NMB-Posibank of andere dochters van ING. Ter adstructie, woordvoerders van de ING spraken elkaar tegen op dit punt (Het Financieele Dagblad. 2 mei 1992). Het argument dat ING geeft ter ondersteuning van het bedrijfseconomische principe dat segmentatie van het eigen vermogen onmogelijk maakt, is minder bevredigend. Immers, het beroep op het 'bedrijfseconomische principe' werd gedaan in 1991, toen de ING nog niet had besloten aparte jaarrekeningen te publiceren voor halr bedrijfsonderdelen. Beleggers wisten derhalve niet of raadpleging van aparte jalarrekeningen mogelijk zou zijn.

De NVB/VvV-werkgroep lanceerde tevens een nieuw model voor de geconsolideerde jaarrekening dat door gemengde financiële concerns kon worden gehanteerd in hun verslaggeving. Een analyse van de jaarrekeningen over 1991 van de gemengde fïnanciële concerns geefi alan dat ING en Realal het model van de werkgroep het meest nauwkeurig volgen voor zowel de balans als de winst-en-verliesrekening. Opmerkelijk is dat Forlis meer publiceert dan anbevolen wordt door de werkgroep (Van der Tas. 1993).

Het is van belang op te merken dat het Ministeric van Justitie de activiteiten van de werkgroep initieerde en stimuleerde. Grosso modo stemde de zienswijze van het Ministerie en die van de werkgroep overeen. In de voorbereidingstase van het advies was er dan ook contact tussen het Ministerie en de werkgroep. Nictemin groeide binnen het Ministeric het gevoel dat er onenigheid binnen de werkgroep bestond, vooral tussen ING en Forlis. Met het oog daarop formuleerde het Ministerie reeds voordat het advies werd gepubliceerd zijn eigen standpunt over de separate verslaggeving (interview met $\mathrm{S}$. Wortmann).

Het was in het belang van zowel het Ministerie van Justitic als de bedrijlstak dat de verslaggevingspraktijk van gemengde financiële concerns niet te veel uiteen zou lopen. Indien de controverse over de wijze van verslaggeving ertoe zou leiden dat de jaarrekeningen binnen de bedrijfstak volstrekt onvergelijkbaar zouden worden, was er gegronde aanleiding voor de Europese Commissie om haar regelgevingsproces 
te versnellen en haar zienswijze aan de bedrijfstak op te leggen. Verder zou een gesloten front ook cen betere kans van slagen maken in de Nederlandse parlementaire behandeling van de voorgestelde verslaggevingsmethodiek (interview met S. Wortmann). De parlementaire behandeling is hel onderwerp van de volgende paragrataf.

\subsection{De parlementaire behandeling van het wetsworstel}

De Tweede Kamer-commissie wachtle op de publicatie van het NVB/VvV-advies voordat ze begon met haar voorbereidend onderzoek inzake het wetsvoorstel in het eerste kwartal van 1992. In het Voorlopig Verslag maakte de CDA-commissieleden gewag van hun teleurstelling over het bedrijfstakadvies, dat zij beschouwden als een compromisstuk. Het CDA had de stellige indruk dat het advies het resultaat was van een beduidende controverse in de werkgroep. watarbij uiteindelijk de ING als winnaar uit de bus was gekomen. Als representatie van de mening van een enkeling (de ING) werd het bedrijfstakadvies dan ook minder serjeus genomen door de christen-democraten (interview met Th. Vreugdenhil).

Hel CDA maakte in zijn reactie duidelijk dat de rode dralad in de bankenverslaggevingsrichtlijn het 'vergelijkbalarheidsconcept' was. De jaarrekeningen van vergelijkbare ondernemingen dienen niet te zeer te verschillen. Het niet-segmenteren van het geconsolideerde eigen vermogen werd gezien als kenmerkend voor het gebrek aan vergelijkbaarheid van jaarrekeningen, dat zou ontstaan door het implementeren van het wetsvoorstel en het werkgroepadvies. De christen-democraten stelden dan ook voor om afzonderlijke geconsolideerde jalarrekeningen verplicht te stellen voor zowel het gehele gemengde concern als de twee onderdelen: de bankaktiviteit en de verzekeringsactiviteit (Voorlopig Verslag 22169, nr. 4, p. 1-2).

Het belang dat het CDA hechtte aan de vergelijkbaarheid van jaarrekeningen is opvallend, zeker omdat dit lijkt in te druisen tegen het overheersende inzichtsprincipe. Het CDA wilde echter een belangrijke stem geven aan de belangen van beleggers, die voor hun meningsvorming meer gediend zouden zijn met vergelijkbare jaarrekeningen. Het was dan ook een grote beleggingsmaatschappij die Vreugdenhils (CDA) aandacht vroeg voor de voordelen van vergelijkbare jalarverslagen. Hoewel de CDAwoordvoerder in die tijd meerdere gemengde financiële concerns bezocht, was het belang van de beleggingsmalatschappij overheersend in zijn meningsvorming (interview met Th. Vreugdenhil).

In dit stidium van het wetgevingsproces leverde alleen het CDA commentaar op de voorstellen over de gemengde financiële concerns. De regering antwoordde dat naar haar mening gemengde financiële concerns niet onderworpen waren alan de banken- of de verzekeraarsverslaggevingsrichtlijn (Memorie van Antwoord. 22169. nr. 5. p. 2-3). Nu er in het buitenland noch in Nederland enig houvast was voor de verslaggeving door deze ondernemingen. moest het NVB/ $\mathrm{V} \vee \mathrm{V}$-advies worden gewardeerd als een eerste poging om de problemen in kalart te brengen en mogelijke oplossingen te schetsen. In het kader vall de nadere segmentatie van het geconsolideerde eigen vermogen stelde de regering dat de voortschrijdende verstrengeling van bank- en verzekeringsactiviteiten weerspiegeld diende te worden in de jaarrekening. De geconsolideerde jaarrekening was bij uitstek het geschikte medium om hier uitdrukking aan te geven.

De regering stelde tevens dat gezien de bijzondere positie van financiële instellingen en hun invloed in het economisch systeem, het geconsolideerde jaarverslag alleen niet kan volstaan. Omdat banken en verzekeraars tot op dat moment altijd gescheiden hadden geopereerd, was het vooralsnog mogelijk om informatie over de twee afzonderlijke activiteiten te verstrekken. De vralag daarbij was op welke wijze (gehanteerde methode) dat zou moeten gebeuren, en tol op welk niveau van informatieverstrekking men dairbij zou moeten galan, aldus de regering. De regering stelde voor dat inzicht in beide activiteiten zou moeten worden gegeven zoals vastgesteld in de banken- en verzekeraarsverslaggevingsrichtlijn. Dit voorstel werd neergelegd in een Nota van Wijziging (22169, nr. 6, p. 1) met betrekking tot artikel 406. Aan artikel 406 werden drie nieuwe leden toegevoegd, waarvan de leden 4 en 5 in dit kader relevant zijn. De regering stelde dat hatar voorstel in overeenstemming was met het $\mathrm{NVB} / \mathrm{Vv} \mathrm{V}$-advies.

Het is van belang op te merken dat de regering in eerste instantie niet van plan was om expliciete verplichtingen op te nemen in de wet. De alanvankelijke gedachte was on de NVB/VvV-suggesties de (informele) regel te laten vormen. De nieuwe 
leden van artikel 406 werden toegevoegd vanwege de politieke druk van het CDA en de expliciete wens van DNB om op dit gebied wetgeving tot stand te brengen (interview met $\mathrm{S}$. Wortmann en R. Boezer). Achteraf beschouwd, oordeelden zowel het Ministerie van Justitie als de ING (die een belangrijke stem had in de totstandkoming van het NVB/VvV advies) dat het advies anders dan verwacht weinig relevantie had voor de geïmplementeerde regelgeving.

Eén van de belangrijkste opmerkingen van de regering in de Memorie van Antwoord was dat de bewindslieden zich niet wilden vastleggen op de methode waarop het inzicht in beide activiteiten werd verstrekt. Als reden hiervoor wees de regering op de voortgaande verstrengeling van activiteiten in de gemengde financiële concerns. Na verloop van tijd zou er alleen een arbitraire verdeling kunnen worden gemaakt van een ondeelbare eenheid in een bank- en verzekeringstak. Bijgevolg zou een volstrekt onbetrouwbaar beeld ontstaan van de financiële positie van de onderneming. Mocht een gemengd financieel concern echter van mening zijn dat het vereiste inzicht het beste via afzonderlijke verslagen kan worden gegeven, dan was dat niet in strijd met het wetsvoorstel.

Samenvattend: de groeiende vervlechting van bank-en verzekerproducten en -activiteiten leidde ertoe dat de regering voorstelde om het inzichtscriterium te hanteren als een algemene richtlijn voor de jaarverslaggeving door gemengde financiële concerns. Dat inzicht zou moeten worden gegeven in zowel het concern als geheel als de onderscheiden delen. Het werd aan het management van de betrokken ondernemingen overgelaten op welke (accounting)wijze men aan het inzichtscriterium wilde voldoen. Het voorstel van de regering was in grote lijnen in overeenstemming met de wens van de bedrijfstak. In dit stadium van het wetgevingsproces was er consensus over de vraag of bank- en verzekeringsactiviteiten konden worden geconsolideerd in een jaarrekening. Verschil van mening tussen het Ministerie van Justitie en de bedrijfstak enerzijds en het CDA en DNB anderzijds was er op het terrein van separate verslaggeving en meer specifiek over de accounting-methode die zou moeten worden gebruikt om aan het inzichtsvereiste te voldoen.

Het eindverslag van de Tweede Kamer-commissie onderstreepte dit verschil van mening nog eens.
De reactie van het CDA op het Memorie van Antwoord van de regering luidde dat de vergaande verstrengeling van bank-en verzekeringsactiviteiten in theorie wellicht de separate rapportage van beide activiteiten (in een apart verslag) kon belemmeren, maar dat dit in de praktijk moeilijk voorstelbaar was. Het management van het gemengde financiële concern zou immers altijd omwille van de interne sturing informatie wensen over de twee hoofdactiviteiten afzonderlijk. En zelfs al zou dat niet het geval zijn, dan was er altijd nog de verplichting om aan de toezichthouders gedetailleerde separate informatie te verstrekken. Het CDA stelde tevens dat de laissez-faire positie van de regering wat betreft de methode waarmee inzicht in de activiteiten zou moeten worden gegeven in strijd was met de Europese banken- en verzekeraarsverslaggevingsrichtlijnen, en meer nog met de door de regering zelf voorgestelde wijziging van artikel 406. Naar de mening van het CDA stelde het nieuwe artikel 406 immers dat publicatie van met name het eigen vermogen van het bank- en verzekeringsdeel verplicht was.

In dit kader verwees het CDA naar de jaarrekening van Fortis als een voorbeeld dat het mogelijk blijft (ondanks de ontwikkeling van nieuwe financiële producten) afzonderlijk verslag te geven over de hoofdactiviteiten en het concern als geheel. Navraag bij de ING leerde overigens dat ook daar weinig technische obstakels werden gezien voor een separate verslaggeving (interview met W. Badon Ghijben). Klaarblijkelijk is er geen accounting-probleem in het separaat verslaggeven. hoewel de regering dit argument gebruikte.

Het antwoord van de regering op het CDAcommentaar was dat haar voorstel onmogelijk in conflict kon zijn met de aangehaalde EEGrichtlijnen, aangezien geen van beide betrekking had op de gemengde financiële concerns.

De regering gaf het CDA echter gelijk wat betreft de opmerking dat technische problemen separate rapportage niet onmogelijk maken. ${ }^{4}$ Ook was de regering het met het $\mathrm{CDA}$ eens dat de nieuwe leden 4 en 5 van artikel 406 de segmentatie van het eigen vermogen van bank- en verzekeringsdeel op enigerlei wijze noodzakelijk maakte. Derhalve vroeg de regering de Raad voor de Jaarverslaggeving (RJ) om advies. De RJ zou zich nader beraden over de wijze waarop (de methode) inzicht zou moeten worden verstrekt in beide hoofdactiviteiten; het betrof derhalve een concrete 
uitwerking van lid 4 en 5 van artikel 406. Deze adviesaanvraag was een geslaagde poging om artikel 406 ingevoerd te krijgen zonder verdere parlementaire wijzigingen (interview met S. Wortmann).

Opgemerkt dient te worden dat het voorgestelde artikel 406 een behoorlijke vrijheid bood aan de gemengde financiële concerns om hun rapportage naar eigen voorkeur in te richten. Het was zelfs zodanig geformuleerd, dat zowel ING als Fortis, die de meest uiteenlopende voorkeuren vertegenwoordigden, het voorstel konden waarderen. De Nota naar Aanleiding van het Eindverslag $(22169, \mathrm{nr} .8)$ waarin het regeringsstandpunt werd verwoord, vormde het wat abrupte voorlopige einde van de discussie. Artikel 406 werd zonder verdere wijzigingen aangenomen en het hele onderwerp was geen punt van discussie tijdens de plenaire vergadering van de Tweede Kamer (Handelingen TK 20-1481). De Eerste Kamer accepteerde het voorstel eveneens zonder verdere wijzigingen. De parlementaire behandeling van artikel 406 kan worden gezien als het sluitstuk van de eerste fase van het wetgevingsproces in de externe berichtgeving door gemengde financiële concerns. De volgende paragraaf beschrijft de implementatie van de verzekeraarsverslaggevingsrichtlijn die de berichtgevingsvoorschriften voor deze ondernemingen completeerde.

\section{Het wetgevingsproces, deel 2: van verzekeraarsverslaggevingsrichtlijn naar wet}

Deel 2 van het verslag omvat twee onderwerpen. Ten eerste wordt de parlementaire behandeling beschreven van het wetsvoorstel inzake de jaarverslaggeving door verzekeringsmaatschappijen voorzover relevant voor het onderwerp van de gemengde fïnanciële concerns (5.1). Vervolgens wordt aandacht besteed aan de lobbyinspanningen van de ING (5.2).

\subsection{De parlementaire behandeling van het wetsvoorstel}

Op 19 december 1991 werd de EEG-richtlijn betreffende de jaarrekening en geconsolideerde jaarrekening van verzekeringsmaatschappijen vastgesteld (PbEG L374, 31 december 1991). Het wetsvoorstel naar aanleiding van deze richt- lijn werd op 5 november 1992 naar de Tweede Kamer gestuurd. In de Memorie van Toelichting (22896, nr. 3, p. 23) herhaalde de regering haar eerdere opvatting dat gemengde financiële concerns onderworpen zijn aan de inmiddels ingevoerde nieuwe leden 4 en 5 van artikel 406 .

Volgens het commissieverslag benadrukte de CDA-fractie eens te meer dat jaarrekeningen binnen de financiële bedrijfstak vergelijkbaar dienen te zijn (Verslag, 22896, nr. 5, p. 1). De fractie stelde in dit kader voor een wettelijke plicht te ontwerpen voor de organisatiestructuur van gemengde financiële concerns. Deze ondernemingen zouden de vorm moeten krijgen van een moedermaatschappij met daaronder twee dochters die respectievelijk de bank- en verzekeringsactiviteiten zouden bevatten. Alle drie maatschappijen zouden dan een eigen geconsolideerde jaarrekening dienen te publiceren. Op deze wijze zou de financiële positie van het gemengde concern in zijn geheel en van zijn samenstellende delen duidelijk worden. Het idee achter dit voorstel was niet alleen dat beleggers een beter oordeel konden vormen over de onderneming waar zij belang in hebben, maar dat tevens de taak van de toezichthouders vereenvoudigd zou worden door een duidelijke scheiding van activiteiten (interview met Th. Vreugdenhil). Ook de PvdA was van mening dat nadere informatie over de deelactiviteiten van gemengde financiële concerns noodzakelijk was.

De regering antwoordde dat als gevolg van artikel 406 de gemengde financiële concerns reeds in 'behoorlijk wat' informatie over de afzonderlijke activiteiten dienden te voorzien. De voorzieningen in artikel 406 waren juist geïmplementeerd om te voorkomen dat een concern slechts één jaarrekening zou publiceren zonder inzicht te geven in de afzonderlijke delen (Nota naar aanleiding van het Eindverslag, 22896, nr. 6, p. 2).

Klaarblijkelijk was dit antwoord niet naar tevredenheid van de CDA-fractie. Naar haar oordeel was de publicatie van 'behoorlijk wat' informatie over de afzonderlijke activiteiten in de toelichting van het geconsolideerde concernverslag niet voldoende. Het CDA stelde dan ook nogmaals voor om twee additionele jaarrekeningen verplicht te stellen, om zo het inzicht te garanderen (Verslag van een schriftelijk overleg, 22896, nr. 8, p. 2). In haar antwoord stelde de regering dat, hoewel artikel 406 consolidatie 
toestaat, in overeenstemming met de relevante EEG-richtlijnen additionele separate informatie over de activiteiten verstrekt dient te worden.

Dit antwoord was nog altijd niet naar tevredenheid van de Kamer. De leden Vreugdenhil (CDA) en Vermeend ( $\mathrm{PvdA}$ ) dienden een amendement in op artikel 406, waarin de separate verslaggeving door de bank- en verzekeringsdelen van het gemengde financiële concern werd vastgelegd. Formeel werd een nieuw lid 6 toegevoegd aan artikel 406 dat bepaalt dat afzonderlijke balansinformatie moet worden verstrekt, in overeenstemming met de vormvereisten van de EEG-richtlijnen. Deze separate verslaggeving zou informatie moeten bevatten over het eigen vermogen van de bank-en verzekeringsactiviteiten.

Dit amendement omzeilde de laissez fairehouding van de regering inzake de methode waarmee inzicht in de bank- en verzekeringsactiviteiten wordt verschaft. In plaats van de ruime verslaggevingskeuzen die de regering (en de bedrijfstak) propageerden, werden de vereisten en het raamwerk van de beide EEG-richtlijnen opgelegd. Het wetsvoorstel werd vervolgens alangenomen door de Tweede en Eerste Kamer.

\subsection{De bë̈vloedingspogingen van de ING}

Een belangrijke vraag blijft onbeantwoord. Wat bracht Vreugdenhil en Vermeend ertoe een amendement in te dienen waarin de methode waarmee inzicht zou moeten worden verschaft, werd gespecificeerd, inclusief de verplichting om het eigen vermogen te alloceren over de twee hoofdactiviteiten? Twee redenen kunnen hiervoor worden aangehaald. In een gesprek met Vreugdenhil stelde een ING-topmanager dat het oorspronkelijke artikel 406 (vóór het amendement) zodanig geïnterpreteerd kon worden dat gemengde financiële concerns niet noodzakelijkerwijs de EEGrichtlijnen (inzake de vormvereisten) behoefden te volgen voor de verslaggeving over de individuele activiteiten. Ook zou het niet noodzakelijk zijn om het eigen vermogen te segmenteren over de banken verzekeringsactiviteiten. Deze interpretatie werd door de ING toegepast in de jaarrekening over 1992, waarin het eigen vermogen niet is gesegmenteerd (interviews met Th. Vreugdenhil en W. Badon Ghijben).

Ten tweede was door de regering in de parle- mentaire behandeling van de Wet inzake de jaarverslaggeving door banken aangekondigd dat de RJ om advies was gevraagd aangaande de toepassing en nadere invulling van artikel 406 in het kader van de verslaggeving door gemengde financiële concerns. Vreugdenhil vernam uit RJkringen dat de RJ er niet in slaagde overeenstemming te bereiken over dit onderwerp. De RJ had een werkgroep ingesteld die de plenaire raad hierover moest adviseren, en deze werkgroep adviseerde tegen publicatie van gesegmenteerde informatie (met name voor het eigen vermogen), een en ander in overeenstemming met de positie van ING (interviews met Th. Vreugdenhil en W. Badon Ghijben).

Dit advies van de RJ-werkgroep wekte weerstand binnen de voltallige Raad. Met name de accountants- en de gebruikersdelegatie binnen de RJ maakten bezwaar tegen de implicaties van het advies; zij waren voorstander van meer informatieverstrekking. Vreugdenhil concludeerde daarop dat de ING wederom de partij was die een oplossing tegenwerkte. Vreugdenhil stelde dat de ING als belangrijke contribuant aan het VNO een zwaarwegende stem heeft in de werkgeversdelegatie van de RJ en zodoende de mogelijkheid heeft een advies significant te beïnvloeden (interview met Th. Vreugdenhil). Kortom, ING's tegenwerking van de kerngedachte van het bestaande artikel 406 leidde tot het Vreugdenhil/Vermeendamendement.

Waarom was ING gekant tegen de implementatie van de artikel 406-verplichtingen? Het CDA meende dat de fusiepartner van Nationale Nederlanden, de NMB-Postbank, vóór de ING-fusie een zwakke vermogenspositie had. In het fusieproces zouden er belangrijke vermogensverschuivingen hebben plaatsgevonden ten gunste van de voormalige NMB die in het verleden een agressieve marktpolitiek had gevoerd, met inherent hoge risico's (interview met Th. Vreugdenhil). Een analyse van de relevante jaarrekeningen biedt weinig indicatie dat dit CDA-scenario de feitelijke gang van zaken beschrijft.

De ING zelf ontkent dat vermogensverschuivingen de reden waren voor haar oppositie. De ING stelt dat ze eenvoudigweg als een ondeelbaar geheel gezien wilde worden, en dat één geconsolideerde jaarrekening daartoe een uitste- 
kend signial is. De wens om als ondeelbaar geheel gezien le worden had een strategische reden.

Een alantal financieel-analisten betwijfelde openlijk de haalbaarheid van een fusie lussen banken en verzekeraars (Barkemal et al. 1992: Keiser. 1993). De ING wilde derhalve niet beklemtonen dat zij de uithomst was van een fusic van twee takken die voorheen onverenigbaar werden geacht. Op een bepaalde manier zou separate verslaggeving aan de belegger het signalal geven dat zells de ING niet zeker was van het welslagen van een fusie tussen cen bank en een verzekeraar (interview met W. Badon Ghijben).

In dit kader kan overigens opgemerk 1 worden dat de financiële pers erg kritisch was over de heersende praktijk van verslaggeving door zowel banken als verzekeralars als met name gemengde financiële concerns. Financiële journalisten benadrukten herhaaldelijk dal het regelgevingsproces van de verslaggeving door deze ondernemingen zeker moest stellen dat voldoende gedetailleerde inlormatic zou worden verstrekt. Met name de concentratic van macht bij gemengde financiële concerns was een punt van bezorgdheid in de pers. Meer informatieverstreking zou de in het voordeel van de ondernemingen doorgeschoten balans enigszins in evenwicht kunnen brengen (Het Financiecle Dagblat. 2-5-1992, 1.3-111992: FEM. 1.3-6-1992: Hers. 1993a. 1993b; Keiser. 199.3).

Hocwel de ING tegenstander was van het segmentatievoorstel, erkende zij uiteindelijk dat het zeer waarschijnlijk was dat het bedoelde voorstel omgezet zou worden in een wet. Zoals gezegd had Vreugdenhil in april 1993 een gesprek met cen topmanager van ING. In dat gesprek trachtte de ING-manager Vreugdenhil ervan te overtuigen dat de segmentatie van het eigen vermogen geen waardevolle toevoeging zou zijn aan de informatieverschaffing naar beleggers.

Eveneens bracht de ING-manager een ander aspect van hel verzekeringswelsvoorstel naar voren dal onwenselijk werd geacht door de verzekeringsbedrijfstak. In het wetsvoorstel (22896) werd gesteld dat onroerend goed in eigen gebruik door verzekeratars moest worden afgeschreven (Memorie van Toelichting. 22896, nos. 1-2. p. 9). Hoewel er diepgaande discussies over dit punt waren geweest tussen het Ministeric van Justitie en de verzekeraars. hield het ministerie vast aan zijn voorstel. Het
Verbond van Verzekeraars had in een brief aan de Tweede Kamer reeds gevraigd dit punt te amenderen. De ING-manager deed Vreugclenhil de suggestie dat hij een amendement zou kunnen indienen in overeenstemming met de wens van de verzekeratars. In dat geval was de ING wel bereid halar weerstand tegen de segmentalie terzijde te stellen (interviews met Th. Vreugdenhil en W. Badon Ghijben).

\section{De rol van de accountants}

Het is relevant aandacht te besteden aan de activiteiten van accountants. De markl voor accountantsdiensten voor gemengde linanciële concerns werd bijna volledig gedomineerd door twee bedrijven: Moret Ernst \& Young (MEY) en KPMG. Gedurende de presentatic van het jaarverslag 1991 van MEY malakte de toenmalige vicevoorzitter een aantal opmerkingen over verslaggeving door financiële concerns. Het Financieele Dagblad berichtte nalar alanleiding van de betreffende presentalic dat naar de mening van de vicevoorzitter van MEY separale verslaggeving verplicht zou moeten zijn voor gemengde financiële concerns (Het Financieele Dagblad. 25-3-1992).?

Deze mening stond haaks op de belangen van de grootste cliënten valn MEY. die slechts een beperkte graad van segmentatie voorstonden (ING was één van MEY's cliënten). Ook was de verklaring van $M E Y$ in tegenspralak met de aanbeveling van het NVB/VvV-advies. De vicevoorzitter maakte zijn opmerkingen na publicatie van dil advies, maar vóór de parlementaire behandeling. Bij het Ministerie van Justitie onstond enige onrust over het feit dat één van de grootste accountantskantoren in het land een positie innam die duidelijk afweek van het ministeriële beleid. Het Ministerie nam derhalve contact op met MEY om een nadere toelichting. De toelichting luidde dat het commentalar van de vice-voorzitter niet de officiële positie van het accounlantskantoor weergaf, maar slechts zijn persoonlijke opvaltingen (interview met S. Wortmann). Ook ING nam kennis valn deze uitlatingen en uitte haar verontwalardiging in stellige bewoordingen (interview met W. Badon Ghijben). Ook hier bleck dat de verantwoordelijke partner van MEY er een andere mening op na hield dan de vice-voorzitter, nalar wiens commentaar werd verwezen als een 'interne communicatiefoul' (intervicw met W. Badon Ghijben). 
De betrokkenheid van accountants was niet beperkt tot deze gebeurtenis. Veel van de activiteiten waren echter geconcentreerd op het circuit van de Raad voor de Jarverslaggeving. Zo was de voorzitter van de werkgroep die de RJ instelde om een advies voor te bereiden. een accountant van een groot kantoor. Dit kantoor had echter weinig cliënten in de bedrijfstak van de financiële conglomeraten.

\section{Ten slotte}

In dit artikel is verslag gedaan van het wetgevingsproces inzake de jaarverslaggeving door gemengde financiële concerns. Met name is aandacht besteed aan de interactie tussen belangengroepen. Er is tot op heden weinig wetenschappelijk onderzoek verricht naar de totstandkoming van regelgeving op het gebied van de externe berichtgeving. Het bestilande (niet-Nederlandse) onderzoek is meestentijds gericht op het formele regelgevingsproces. Een dergelijke benadering verwalarloost een onderdeel van het proces dat waarschijnlijk tot het meest belangrijke gerekend kall worden: het informele circuit. de gebeurtenissen achter de schermen.

Ook in hel ontwerp en de implementatie van de regels voor gemengde financiële concerns is gebleken dat veel van de interactie op informele wijze plaatsvindt. en zelfs van doorslaggevende betekenis kan zijn geweest. De resultaten van dit onderzoek pleiten dan ook voor het verbreden valn de standaardmethodologie in het lobbyonderzoek.

Met betrekking tol de uiteindelijke uitkomsten van het wetgevingsproces kan worden geconcludeerd dat de wensen van de gebruikers van de jatarrekening van gemengde financiële concerns het best tot uitdrukking komen in het resulterende artikel 406. Dit artikel garandeert dat bank- en verzekeringsactiviteiten geconsolideerd worden en dat voldoende afzonderlijke inlormatie wordt verschaft over de onderdelen van het concern. inclusief informatie over de allocatie van het eigen vermogen. Vooral de eerdergenoemde grote beleggingsinstelling en de financiële pers blijken een belangrijke stem te hebben gehad in de totstandkoming van deze wetgeving.

Hoewel de voorkeuren van de gemengde fïnanciële concerns uiteenliepen, vormden de ondernemingen toch min of meer een gezamenlijk blok. Zij propageerden een berichtgevingsvoorschrift dat zodanige vrijheid aan de ondernemingen bood dal de twee meest divergerende verslaggevingspraktijken (die van de ING en Fortis) geaccommodeerd konden worden. De accountants van de gemengde financiële concerns steunden over het algemeen de zienswijze van hun cliënten. Welbeschouwd ontstonden twee blokken: de gebruikers en DNB aan de ene zijde. en de gemengde financiële concerns en hun accountants alan de andere zijde. Het Ministeric van Justitie werkte in deze discussie nauw samen met de bedrijfstak, terwijl het parlement (en met name de CDA-fractie) vooral oog had voor de wensen van de gebruikers.

De belanghebbende partijen verschillen in de mate waarin zij gelegenheid hebben te participeren in het formele wetgevingsproces. Er zijn met name ook belangrijke verschillen in de mate warin de partijen tocgang hebben tot sleutelfunctionarissen in het wetgevingsproces. De ondernemingen en DNB namen uitdrukkelijk deel alan de voorbereiding van de wetsvoorstellen zowel op Europees als Nederlands niveau. Het Ministeric van Justitie nodigde de betrokken ondernemingen zelfs uitdrukkelijk uit te contribueren aan de discussies. De gemengde financiële concerns en de eerder in het artikel genoemde grote beleggingsmaatschappij hadden verder rechtstreekse toegang tol de CDA-woordvoerder op verslaggevingsgebied. De gebruikers waren vooral angewezen op meer indirecte middelen, zoals artikelen in de financiële pers. om hun mening te laten horen.

Hoewel ondernemingen in het algemeen hun invloed op de wet- en regelgeving in de externe berichtgeving beter geinstitutionaliseerd blijken te hebben. zijn andere belangenhebbenden, in ieder geval in dit wetgevingsproces, in staat hun mening te uiten en invloed uit te oefenen op het besluitvormingsproces.

\section{I T E R A T U U R}

Advies jaarrekening bankverzekeraars, In: Het Financieele Dagblad, 4 februari 1992.

Amershi, A.H., J.S. Demski, en M.A. Wolfson, (1982), Strategic Behaviour and Regulation Research in Accounting, In: Journal of Accounting and Public Policy, vol. 1 
Banken en verzekeraars zitten op elkaars lip, In. Het Financieele Dagblad, 25 februari 1992.

Barkema, H.G., S.W. Douma en B.T.M. Steins Bisschop, (1992), Analyse van een fusie. Strategische, financieeleconomische en juridische aspecten van de fusie tussen Nationale-Nederlanden en de NMB-Postbank Groep. Schoonhoven: Academic Service.

Burgert, R., C.W.A. Timmermans en H.F.J. Joosten, (1990), De jaarrekening nieuwe still, 6e gewijzigde druk, Alphen a/d Rijn: Samsom H.D. Tjeenk Willink.

Financiële concerns maken ratjetoe, In: FEM, vol. 23, 13 juni 1993.

Hers, F., (1993a), Verzekeringslobby scoort, In: FEM, vol. 24, 6 maart 1993.

Hers, F., (1993b), Verzekeraars, meer realisme graag, In: FEM, vol. 24, 6 maart 1993.

ING brengt met eigen CAO bancassurance in het spel, In: Het Financieele Dagblad, 3 december 1993.

Jaarverslag ING biedt nog minder dan ABN AMRO, In: Het Financieele Dagblad, 2 mei 1992

Keiser, H., (1993), Weg met All Finanz, In: FEM, vol. 24, 24 juli 1993

Lent, L.A.G.M. van, (1995), Pressure and Politics in Financial Accounting Regulation, In: Research Memorandum FEW 686, Katholieke Universiteit Brabant.

Lent, Laurence van, (1997), Pressure and Politics in Financial Accounting Regulation: The Case of the Financial Conglomerates in the Netherlands, In: Abacus, vol. 33, nr. 1, pp. 88-114.

Lindahl, F.W., (1987), Accounting Standards and Olson's Theory of Collective Action, In: Journal of Accounting and Public Policy, vol. 6

Loflied op verzekerbanken verstilt, In: Het Financieele Dagblad, 13 november 1992.

Moret: separate rapportage nodig bij banken, In: Het Financieele Dagblad, 25 maart 1992.

Sutton, T.G., (1984), Lobbying of Accounting Standard-Setting Bodies in the UK and the USA: A Downsian Analysis, In: Accounting, Organizations and Society, vol. 9

Tas, L.G. van der, (1993), Verslaggeving door gemengde financiële instellingen, In: M.N. Hoogendoorn en R. van der Wal (red.), Jaar-In-Jaar-Uit 7, Groningen: WoltersNoordhoff.

Walker, R.G. en S.P. Robinson, (1993), A Critical Assessment of the Literature on Political Activity and Accounting Regulations, In: Research in Accounting Regulation.

Watts, RL. en J.L. Zimmerman, (1978), Towards a Positive Theory of the Determination of Accounting Standards, In: The Accounting Review, vol. 53.

Yin, S., (1989), Case study research, rev. ed, Newbury Park Sage.

\section{B I J L A G E}

Tabel 1: Interviews met sleutelinformanten

\begin{tabular}{lll}
\hline Datum & Infornant & Organisatie \\
\hline $08 / 07 / 1994$ & M.W. Noordzij & VNO \\
$17 / 08 / 1994$ & Th. O. Vreugdenhil & CDA \\
$05 / 09 / 1994$ & S. Wortuann & Ministerie van Justitie \\
$13 / 09 / 1994$ & W. Badon Ghijben en & \\
& J. Kuijper & ING \\
$29 / 09 / 1994$ & R.E.K. Boezer & De Nederlandsche Bank
\end{tabular}

\section{N O T E N}

1 Dit artikel is geschreven gedurende een verblijf als visiting researcher aan de William E. Simon Graduate School of Business Administration van de University of Rochester. Een uitgebreidere versie van dit artikel is eerder verschenen als Van Lent (1997). De constructieve opmerkingen van Gijs Bak, Graeme Dean, Hugh Lambert, L.G. van der Tas en Jerold Zimmerman gedurende dit onderzoeksproject hebben een wezenlijke bijdrage geleverd aan het eindresultaat. Dank is ook verschuldigd aan J. Kuiper en R. Remmerswaal (beide verbonden aan de ING) alsmede aan R. Boezer (De Nederlandsche Bank) voor hun suggesties naar aanleiding van deze publicatie.

2 Men bedenke hierbij tevens dat het CDA indertijd nog de grootste partij in de Tweede Kamer was, en dat bijgevolg de fractiewoordvoerder een niet te verwaarlozen stem had in de wetgevingsprocedure.

3 In 1991 konden zeven ondernemingen als gemengd financieel concern worden gekenmerkt: ABN AMRO, Aegon, Fortis, ING, Levob, Reaal en Rabobank.

4 Ook het Ministerie van Justitie achtte dit argument a priori zwak, maar beschouwde het politiek opportuun in de parlementaire discussies (interview met S. Wortmann)

5 Uit correspondentie naar aanleiding van dit artikel is gebleken dat de toenmalige vice-voorzitter van Moret Ernst \& Young van mening is dat Het Financieele Dagblad zijn opvattingen terzake onjuist heeft weergegeven. Deze lezing van de voornoemde vice-voorzitter wordt niet bestreden in dit artikel Echter, de partijen in dit regelgevingsproces verkeerden vanwege de rapportage in Het Financieele Dagblad in de overtuiging dat Moret Ernst \& Young geen voorstander was van separate verslaggeving. Hun handelingen zijn op deze beeldvorming gebaseerd. Het is dan ook deze beeldvorming en niet de daadwerkelijke opvatting van de vice-voorzitter van Moret Ernst \& Young - die van belang is voor de totstandkoming van de regelgeving 